\title{
Prioritizing resident and patient safety while maintaining educational value: emergency restructuring of a Canadian surgical residency program during COVID19
}

\author{
Nada Gawad, MD, MAEd \\ Chelsea Towaij, MD \\ Tommy Stuleanu, MD \\ Carlos Garcia-Ochoa, MD \\ Lara J Williams, MD, MSc
}

Accepted May 11, 2020

\section{Correspondence to: \\ L. Williams \\ The Ottawa Hospital \\ Civic Campus \\ 305-737 Parkdale Ave \\ Ottawa ON K1Y 4E9 \\ larwilliams@toh.ca}

DOI: $10.1503 /$ cjs. 006120

\begin{abstract}
SUMmaRY
Surgical programs are facing major and fluctuating changes to the resident workforce because of decreased elective volumes and high exposure risk during the coronavirus disease 2019 pandemic. Rapid restructuring of a residency program to protect its workforce while maintaining educational value is imperative. We describe the experience of the Division of General Surgery at the University of Ottawa in Ontario, Canada. The residency program was restructured to feature alternating "on" and "off" weeks, maintaining a healthy resident cohort in case of exposure. Teams were restructured and subdivided to maximize physical distancing and minimize resident exposure to pathogens. Educational initiatives doubled, with virtual sessions targeting every resident year and incorporating intraoperative teaching. The divisional research day and oral exams proceeded uninterrupted, virtually. A small leadership team enabled fast and flexible restructuring of a system for patient care while prioritizing resident safety and maintaining a commitment to resident education in a pandemic.
\end{abstract}

T he coronavirus disease 2019 (COVID-19) pandemic presents an unprecedented challenge to health care. As of April 19, 2020, Ontario had approximately 10500 confirmed cases ${ }^{1}$ and adopted physical distancing as a cornerstone of fighting viral spread. ${ }^{2}$ Although critical, self-isolation requirements can become disruptive to health care delivery. Health care providers are at high risk of exposure, leaving wide gaps in clinical coverage as they self-isolate. A recent American study described a residency restructuring model, but no Canadian experiences or comment on the educational component of surgical training during the COVID-19 pandemic have been described. ${ }^{3}$

Surgical oncology cases represent a workflow challenge, as health systems struggle to balance priorities in cancer care with the conservation of resources. The Cancer Care Ontario (CCO) Pandemic Guideline classifies these cases into 3 priority levels based on acceptable delay to surgery, ${ }^{4}$ and each hospital manages its own resources within this framework. At The Ottawa Hospital (TOH), oncology cases are triaged weekly by senior management. All elective, nononcology surgery has been postponed indefinitely.

Foreseeing the impact on patient care and resident education, the University of Ottawa's general surgery program leadership team (L.W., N.G., C.T.) designed a contingency schedule. The small leadership team was key to being able to develop and implement widespread changes swiftly. The leadership team is in frequent communication with residents, staff and other key stakeholders in hospital administration, which allows for rapid adjustments in response to daily updates. Our objectives were as follows: 
1. Ensure resident coverage for clinical activity while minimizing in-hospital exposure;

2. Maximize the continuity of patient care, while minimizing the number of residents required in hospital;

3. Maximize resident education given the decrease in clinical learning opportunities.

\section{Program Restructuring}

\section{Available pool of residents}

The University of Ottawa general surgery program is home to 32 residents, 2 of whom are research residents. Senior residents (postgraduate years [PGY] 3-5) are all available after being recalled from their planned off-site or elective, ambulatory, or endoscopy rotations.

\section{Coverage needs}

Inpatient surgical services are split between the General Campus (oncology centre) and the Civic Campus (trauma centre), and residents are divided among subspecialty teams at each campus. While many teams were expected to dramatically slow activity, the volumes faced by acute care surgery (ACS), trauma and oncology teams have been unpredictable. Outpatient clinics have transitioned to a telehealth model, minimizing resident involvement. Nighttime coverage needs remained unchanged, with 1 junior and 1 senior resident at each site.

\section{Physical distancing measures}

Under the contingency schedule (Fig. 1, Table 1 and Table 2), each resident team functions independently, without crossover among team members or patient exposures. All handovers are virtual. Within ACS teams, residents are subdivided into day coverage and back-up day coverage plus night coverage. Subteams further minimize the ramifications of an exposure. One member of each team is designated to have patient contact, while all other team members either remain in the hallway or join rounds virtually. Each consult is designated to be appropriate for physical exam by either a junior or senior resident, as opposed to both, to minimize duplicate exposures before reviewing with staff surgeons. General surgery residents are isolated to an exclusive designated workspace to minimize time in patient care areas and exposure to other health care workers. Furthermore, our electronic medical record allows routine patient care duties to happen remotely, again providing opportunity for physical distancing from the inpatient units.

\section{Maintaining a healthy pool of residents in case of exposure}

By consolidating our elective subspecialty services, we have been able to minimize the number of residents providing in-house care at any given time. Residents

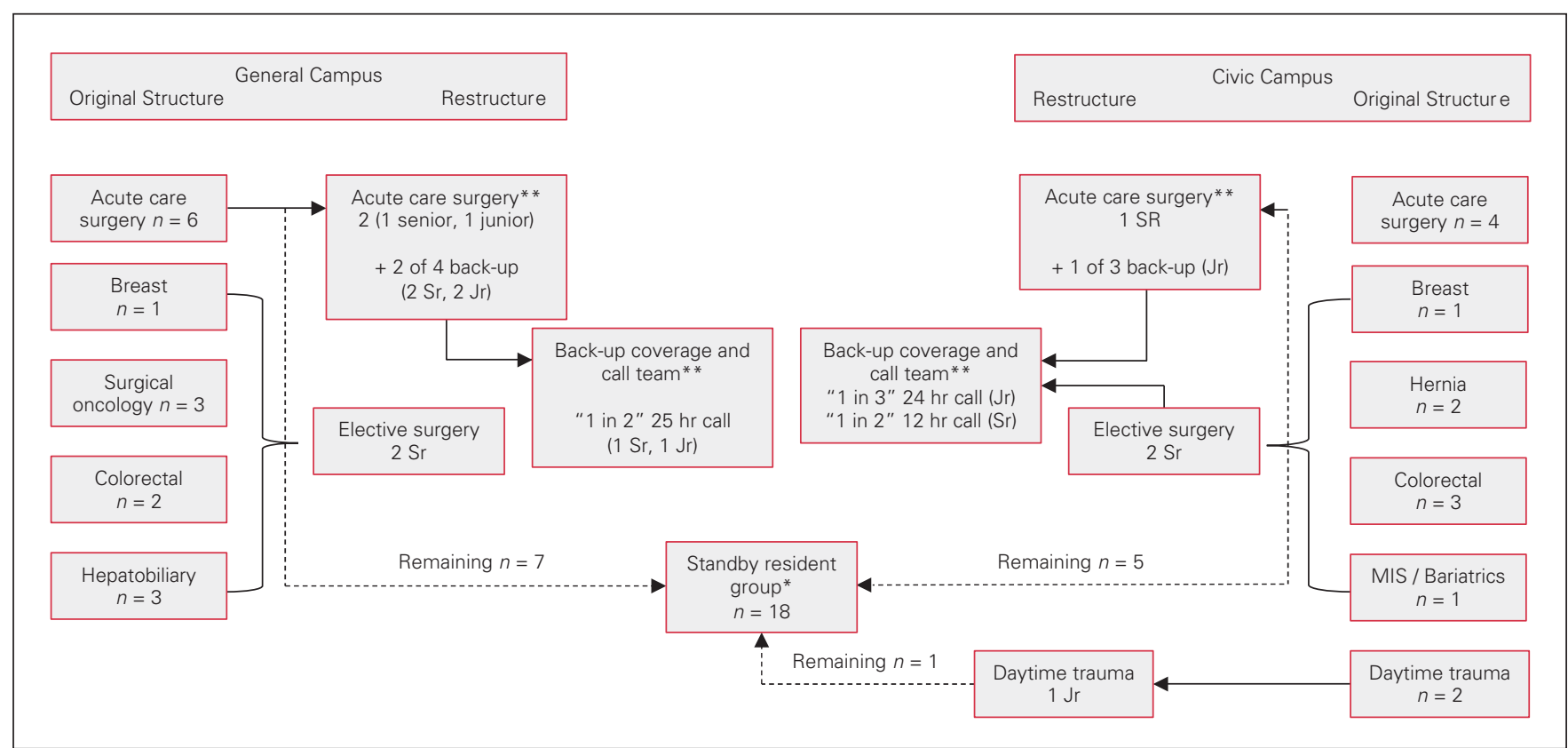

Fig. 1. Diagram of emergency restructuring of preexisting acute care surgery (ACS) and subspecialty resident teams to 1 ACS and 1 elective team per campus. Numbers for each subspecialty within the original structure boxes indicate the usual number of residents per service. *Standby resident group includes 2 research residents as well as more residents than usually available given recall from community sites and electives. **See Table 1 and Table 2 for further clarification of the daily ACS workflow. $\mathrm{Jr}=$ junior; $\mathrm{Sr}=\mathrm{senior}$. 
Table 1. Sample week at General Campus featuring consistent and separate daytime coverage for ACS and elective teams, as well as back-up daytime coverage with nighttime coverage provided by " 1 in 2 " 24 -hour call team comprising a paired senior and junior resident team*

\begin{tabular}{|c|c|c|c|c|}
\hline Day & $\begin{array}{l}\text { ACS day Sr } \\
\text { (6am-5pm) }\end{array}$ & $\begin{array}{l}\text { ACS day Jr } \\
\text { (6am-5pm) }\end{array}$ & $\begin{array}{l}\text { 24-hour call } \\
\text { team } \\
\text { (6am-6am) }\end{array}$ & $\begin{array}{c}\text { Elective team } \\
\text { (6am-5pm) }\end{array}$ \\
\hline 1 & Sr A & Jr A & $\mathrm{Sr} B+\mathrm{Jr} B$ & $\operatorname{Sr} D+\operatorname{Sr} E$ \\
\hline 2 & Sr A & $\operatorname{Jr} A$ & $\mathrm{Sr} C+\mathrm{Jr} C$ & $\operatorname{Sr} D+\operatorname{Sr} E$ \\
\hline 3 & Sr A & $\operatorname{Jr} A$ & $\mathrm{Sr} B+\mathrm{Jr} B$ & $\operatorname{Sr} D+\operatorname{Sr} E$ \\
\hline 4 & Sr A & $\operatorname{Jr} A$ & $\mathrm{Sr} C+\operatorname{Jr} C$ & $\operatorname{Sr} D+\operatorname{Sr} E$ \\
\hline 5 & Sr A & $\operatorname{Jr} A$ & $\mathrm{Sr} B+\mathrm{Jr} B$ & $\operatorname{Sr} D+\operatorname{Sr} E$ \\
\hline 6 & Sr A & $\mathrm{Jr} A$ & $\mathrm{Sr} C+\mathrm{Jr} C$ & $\operatorname{Sr} D+\operatorname{Sr} E$ \\
\hline 7 & $\operatorname{Sr} A$ & $\operatorname{Jr} A$ & $\mathrm{Sr} B+\mathrm{Jr} B$ & $\operatorname{Sr} D+\operatorname{Sr} E$ \\
\hline \multicolumn{5}{|c|}{$\begin{array}{l}\text { ACS = acute care surgery; OR = operating room. } \\
\text { *Higher resident numbers due to higher volume of ACS service as well as more elective } \\
\text { ORs due to higher oncology volumes at this site. }\end{array}$} \\
\hline
\end{tabular}

are scheduled to rotate weekly between time off and acute, elective, and/or on-call coverage (1 week on, 1 week off). The residents working at any given time are therefore busy, but well backed-up by the remaining resident cohort at home. Small independent teams help mitigate a potential exposure (and isolation requirement) to any individual members or the entire team. Since the contingency schedule allows more than half of the residents to be home at any given time, there is ample coverage in case exposure or redeployment limits resident availability. Staff coverage remains unchanged, and given excess staff surgeon availability with the decrease in elective surgery, a back-up plan of staff rounding and assisting each other in the operating room $(\mathrm{OR})$ can be implemented in case of resident shortages.

\section{Accounting for complex patient care needs}

Table 2. Sample week at Civic Campus featuring consistent and separate daytime coverage for ACS and elective teams (elective team also provides " 1 in 2 " nighttime coverage given low daytime clinical volume on elective service)*

\begin{tabular}{|c|c|c|c|c|c|}
\hline Day & $\begin{array}{l}\text { ACS day Sr } \\
\text { (6am-5pm) }\end{array}$ & $\begin{array}{l}\text { ACS day Jr } \\
\text { (6am-5pm) }\end{array}$ & $\begin{array}{l}\text { 24-hour call Jr } \\
\text { (6am-6am) }\end{array}$ & $\begin{array}{c}\text { Elective Sr } \\
\text { day + night Sr } \\
\text { (6am-5pm) }\end{array}$ & $\begin{array}{c}\text { Trauma day Jr } \\
\text { (6am-5pm) }\end{array}$ \\
\hline 1 & Sr F & JrD & $J r E$ & $\mathrm{Sr} G$ & $\mathrm{JrG}$ \\
\hline 2 & $\mathrm{Sr} F$ & $\mathrm{JrF}$ & JrD & $\mathrm{SrH}$ & $\mathrm{JrG}$ \\
\hline 3 & SrF & $J r E$ & $J r F$ & $\mathrm{Sr} \mathrm{G}$ & $\mathrm{JrG}$ \\
\hline 4 & $\mathrm{SrF}$ & JrD & $J r E$ & $\mathrm{SrH}$ & $\mathrm{JrG}$ \\
\hline 5 & $\mathrm{Sr} F$ & $\mathrm{JrF}$ & JrD & $\mathrm{Sr} \mathrm{G}$ & $\mathrm{JrG}$ \\
\hline 6 & $\mathrm{Sr} F$ & $J r E$ & $J r F$ & $\mathrm{SrH}$ & $\mathrm{JrG}$ \\
\hline 7 & $\mathrm{Sr} F$ & JrD & $J r E$ & $\mathrm{Sr} \mathrm{G}$ & $\mathrm{JrG}$ \\
\hline
\end{tabular}

ACS $=$ acute care surgery.

*Three junior residents alternate " 1 in 3" rotation of daytime ACS coverage, back-up daytime with nighttime coverage, and postcall days. One junior resident covers trauma every day (trauma merges with all other general surgery coverage overnight). Lower resident numbers due to lower volume ACS service and lower oncology volumes at this site.

Table 3. Teaching distribution before and after structural changes to the general surgery residency program

\begin{tabular}{|c|c|c|c|c|c|}
\hline Before & Format & $\begin{array}{l}\text { Hours per } \\
\text { week }\end{array}$ & After & Format & $\begin{array}{c}\text { Hours per } \\
\text { week }\end{array}$ \\
\hline $\begin{array}{l}\text { Academic } \\
\text { half day }\end{array}$ & In-person & 3 & $\begin{array}{c}\text { Academic } \\
\text { half day }\end{array}$ & Videoconference & 3 \\
\hline $\begin{array}{l}\text { Junior } \\
\text { lecture series }\end{array}$ & In-person & 0.75 & $\begin{array}{c}\text { Junior } \\
\text { lecture series }\end{array}$ & Videoconference & 0.75 \\
\hline $\begin{array}{l}\text { Surgical } \\
\text { foundations }\end{array}$ & In-person & 3 & $\begin{array}{c}\text { Surgical } \\
\text { foundations }\end{array}$ & $\begin{array}{c}\text { Powerpoint, } \\
\text { audio recordings }\end{array}$ & 3 \\
\hline \multirow[t]{4}{*}{ MMC } & In-person & 1 & MMC & Videoconference & 1 \\
\hline & & & $\begin{array}{l}\text { PGY5 led } \\
\text { teaching }\end{array}$ & Videoconference & 2 \\
\hline & & & $\begin{array}{l}\text { Intraoperative } \\
\text { teaching }\end{array}$ & Videoconference & 1 \\
\hline & & & $\begin{array}{c}\text { Subspecialty } \\
\text { teaching }\end{array}$ & Videoconference & 5 \\
\hline $\begin{array}{l}\text { Total hours } \\
\text { per week }\end{array}$ & & 7.75 & & & 15.75 \\
\hline
\end{tabular}

With most elective surgeries deferred during the pandemic, those proceeding are often particularly complex and require prolonged hospital stays. Accordingly, only senior residents are assigned to elective services, which has been possible given the higher ratio of senior to junior residents in our program. This has also ensured that any elective-team resident is comfortable making clinical decisions for these patients (the usual involvement of junior residents requires a closer level of supervision). Junior residents maintain their usual role in decision-making on the acute care and trauma surgery teams, as well as while on-call.

\section{Modifying and increasing educational opportunities}

In addition to usual academic activities, which have all continued via a virtual platform, we recognized an opportunity for increased teaching (Table 3). Attending faculty and PGY5 residents lead small and large group interactive sessions virtually on general surgery topics. Given a limitation placed on the number of OR assistants to conserve personal protective equipment, weekly intraoperative video-based teaching that emphasizes technical considerations in laparoscopic cases was also added.

Our divisional research day and oral exams occur annually and biannually, respectively, and were both converted to 
a virtual platform. The research day was attended by 60 division members who actively participated with questions, while 2 adjudicators scored oral and poster presentations. No change was made to the structure of oral exams beyond conversion to a virtual platform.

\section{ConcLusion}

While program size and clinical volumes differ across residency programs, rapid implementation of a contingency schedule that minimizes resident exposure is essential. A base structure should protect the workforce through physical distancing measures and maintain a healthy cohort of residents in case of an exposure. From this base structure, "back-up" residents are available as volumes increase. Providing alternate methods of delivering resident education is essential, given the anticipated duration of the impact of COVID-19 on clinical training. We have demonstrated the successful implementation of a contingency plan that reflects the importance of providing excellent clinical care, promoting surgical education and cultivating ongoing research, while ensuring the utmost attention to resident safety during a pandemic.
Acknowledgements: The authors acknowledge Danielle Doan, program administrator, for her instrumental help with the logistics of moving educational initiatives to a virtual platform and Dr. Isabelle Raiche, the competency by design and simulation lead, for spearheading the increase in resident teaching, particularly with the unique incorporation of weekly intraoperative teaching.

Affiliations: From the Division of General Surgery, Department of Surgery, Faculty of Medicine, University of Ottawa, Ottawa, Ont.

Competing interests: L. Williams reports receiving authorship royalties from UpToDate. No other competing interests were declared.

Contributors: All authors contributed substantially to the conception, writing and revision of this article and approved the final version for publication.

\section{References}

1. Government of Ontario. COVID-19. Toronto (ON); 2020. Available: https://covid-19.ontario.ca/ (accessed 2020 Apr. 18).

2. Government of Ontario. COVID-19: Stop the spread. Toronto (ON); 2020. Available: https://www.ontario.ca/page/covid-19-stop -spread (accessed 2020 Apr. 18).

3. Nassar AH, Zern NK, McIntyre LK, et al. Emergency restructuring of a general surgery residency program during the coronavirus disease 2019 pandemic: the University of Washington experience. 7AMA Surg 2020; doi: 10.1001/jamasurg.2020.1219.

4. CCO Pandemic Plan Review Group. Pandemic Planning Clinical Guideline for Patients with Cancer. Toronto (ON): Cancer Care Ontario; 2020. Available: https://www.cancercareontario.ca/en/ guidelines-advice/types-of-cancer/64736 (accessed 2020 Apr. 16). 